\title{
Contracting Development
}

\section{Managerialism and Consultants in Intergovernmental Organizations}

Seabrooke, Leonard; Sending, Ole Jacob

Document Version

Accepted author manuscript

Published in:

Review of International Political Economy

DOI:

10.1080/09692290.2019.1616601

Publication date:

2019

License

Unspecified

Citation for published version (APA):

Seabrooke, L., \& Sending, O. J. (2019). Contracting Development: Managerialism and Consultants in Intergovernmental Organizations. Review of International Political Economy, 27(4), 802-827.

https://doi.org/10.1080/09692290.2019.1616601

Link to publication in CBS Research Portal

\section{General rights}

Copyright and moral rights for the publications made accessible in the public portal are retained by the authors and/or other copyright owners and it is a condition of accessing publications that users recognise and abide by the legal requirements associated with these rights.

Take down policy

If you believe that this document breaches copyright please contact us (research.lib@cbs.dk) providing details, and we will remove access to the work immediately and investigate your claim. 


\title{
Contracting Development: Managerialism and Consultants in Intergovernmental Organizations
}

\author{
Leonard Seabrooke and Ole Jacob Sending
}

Journal article (Accepted manuscript*)

\section{Please cite this article as:}

Seabrooke, L., \& Sending, O. J. (2019). Contracting Development: Managerialism and Consultants in Intergovernmental Organizations. Review of International Political Economy, 27(4), 802-827.

https://doi.org/10.1080/09692290.2019.1616601

This is an Accepted Manuscript of an article published by Taylor \& Francis in Review of International Political Economy on 26 Jun २०19, available online:

DOI: http://www.tandfonline.com/10.1080/09692290.2019.1616601

* This version of the article has been accepted for publication and undergone full peer review but has not been through the copyediting, typesetting, pagination and proofreading process, which may lead to differences between this version and the publisher's final version AKA Version of Record. 


\title{
Contracting development: managerialism and consultants in intergovernmental organizations
}

Leonard Seabrooke

Copenhagen Business School $\&^{\circ}$ Norwegian Institute of International Affairs

lse.ioa@cbs.dk

Ole Jacob Sending

Norwegian Institute of International Affairs

ojs@nupi.no

This is the pre-proof version, the final piece is published in Review of International Political Economy 27 (4), 802-827.

https://tandfonline.com/doi/full/10.1080/09692290.2019.1616601

\begin{abstract}
Intergovernmental organizations (IGOs) are now managed with an eye to managerial trends associated with transnational professionals, a view that has ramifications for how IGOs govern their policies and processes. Drawing on interviews and focus groups with staff in IGOs, we trace how managerialism in IGOs is changing how staff perceive work practices. We find that IGOs increasingly rely on consultants to enact policy scripts and to evaluate program success. This signals a subtle yet significant shift from expertise and bureaucratic impartiality, grounded in particular types of knowledge, to skills and flexibility to meet client demands and advance best practice norms according to prevailing world cultural frames. This managerial trend in IGOs is partly driven by stakeholder dynamics but is primarily a normative change in who is seen as having the authority to make claims over professional best practices. Such managerialism is contracting the development policy space. This contraction is partly driven by consultants, who defer to their peers and to donors rather than IGO staff and concerned member states. This work also depletes institutional memory for IGO operations. We trace how IGO staff perceive managerial trends and changes in work practices.
\end{abstract}

CONTACT Leonard Seabrooke 1se.ioa@cbs.dk Department of Organization, Copenhagen Business School, Kilevej 14A, 2000 Frederiksberg, DENMARK 


\section{KEYWORDS}

consultants; intergovernmental organizations; managerialism; professions; expertise; development space; World Polity.

\section{Introduction}

How do managerial trends in world culture change how international organizations work? The answer to this question in International Political Economy and research on international organizations is that managerialism is an internal affair that flows from the purpose of the organization. Intergovernmental organizations (IGOs) are designed by states to work on their respective issues (Koremenos et al. 2001). International non-governmental organizations (INGOs) are created by passionate entrepreneurs and activists to organize campaigns on particular issues (Stroup and Wong 2017). Managerialism is contained within the bureaucratic form of the organization. In this article we suggest that an important part of the new political economy of managerialism (as explored in this Special Issue) is that managerial trends from the world of transnational consultancy are important for how international organizations govern their policies and work practices. Such an effect has been noted by scholars working on international humanitarian affairs (Hopgood 2006; Weiss 2013). Here we discuss how managerial trends towards consultancy in IGOs working on development, economic, and health issues, such as the International Monetary Fund, United Nations Development Programme, World Bank, and World Health Organization. We identify general trends in managerialism across IGOs, as well as locating how IGOs are following this trend at different paces based on their professional and organizational characteristics.

We draw on insights from organizational and institutional theory, to probe how new managerial trends - such as the reliance on consultants to perform core work tasks - are changing how IGOs are organized and perform key tasks. One element here is that the rise of what Meyer and Bromley call the "rise of abstract managerialism", which is a world cultural frame that promotes organization via "strategic planning, quantitative program evaluation, audits, and the use of consultants" (Meyer and Bromley 2013: 374). Abstract managerialism is rolled out alongside discourses of scientism, rights, and empowerment as important to a new rational order (Schofer 2003; Kim and Sharman 2014). 
This rationalization process produces an overlooked tension within IGOs, especially when the formal-legal aspects as bureaucratic organizations are less reflected in the substance of how tasks are performed and how the organization is governed. To get at this decoupling between form and content within IGOs, we study the use of consultants and the systems they have developed to manage them. These systems reflect a new form of professionalism that differ markedly from that associated with an international civil servant that has been the hallmark of IGOs' role and function (Sending 2014). We suggest that managerial trends in IGOs are important to understand because IGOs, such as those studied here, are at the forefront of restructuring economies in ways that affirm the types of knowledge and governance associated with abstract managerialism (Guillén 1994). ${ }^{1}$ If those providing policy content and implementation modalities have converged around abstract managerialism then we should expect to see a narrowing of how IGO work is thought about and conducted.

Meyer and Bromley (2013: 379) suggest that the characteristics of contemporary forms of organization in world culture, including abstract managerialism, can be found in changes in the identity and "means-end purposiveness" of organizations. This includes aspects such as how information is controlled, including the use of individual performance testing measures and the expansion of monitoring over employees. They also include the use of consultants to perform core tasks, based on the belief that skills honed in the market rival those associated with the bureaucratic organizational identity. We trace these elements in select IGOs. Our particular focus is on how staff in IGOs perceive consultants and how the increased reliance on consultants affects how IGOs design policy and implement programs. While studies of how IGO staff adopt pathologies are well known (Barnett and Finnemore 2004; Weaver 2008), and recent research has demonstrated how external actors influence the agendas of IGOs (Hopewell 2015; EagletonPierce 2018), we know little about the relationship between IGOs and consultants, other than the long-standing view that consultants are heavily involved in creating the "politics of the possible in terms of administrative reform" (Harrison 2001: 536).

An increased reliance on external consultants relates directly to the question of how managerialism changes how IGOs govern. Especially important here is how consultants are incentivized to behave in ways that secure future contracts. Consultants' operational modalities favor 'short-termism' and 'work-to-contract' behaviors when conducting work for IGOs. They also aim to harness the interoperability of solutions across different organizational platforms. This contrasts with the idea of civil servants exercising professional judgement as they discuss, 
review, and implement policy. A further worry here is that interoperability comes at the expense of IGOs' institutional memory. Informed by our interviews and focus group sessions, discussed below, we argue that IGO staff see consultants as contracting IGO work practices not only in the sense of outsourcing but also in the contraction of what is administratively feasible and rational. In this way the expansion in the use of consultants is also a change to IGO staff's claims to expertise and 'cognitive authority' (Broome and Seabrooke 2012; Barnett and Finnemore 2004). These developments form part of what Best (2014) calls the emergence of "provisional expertise" as a key element in how contemporary IGOs operate. This implies that what constitutes expertise is more closely linked to the performance of key analytical tasks. A concern here is that there is a broader change where having the skill to operate a task across organizations is more valued than independent expertise (Faulconbridge and Muzio 2008).

We extend the insights from Meyer and Bromley on the macro-cultural framing for world society by investigating micro-processes. Our focus is on IGO staff perceptions of how IGOs work in changing due to managerial trends, especially the increased use of consultants. In this way our study shines light on both the micro-processes and the macro-cultural framing associated with what Wade (2003) refers to as the shrinking of 'development space'. Wade argued that such space is the range of options developing countries have to diversify and upgrade their economies through policies encouraged by IGOs. The greater the range of options the wider the development space, while fewer options narrows the space. Wade found that the World Trade Organization's (WTO) "rhetorical commitment to universal liberalization and privatization" reduced the development space, preventing countries from choosing industrial upgrading policies that developed countries used in the past (Wade 2003: 622). Along with persistent trade tariffs from developed countries, this shrinking of development space trapped developing countries in how they self-determine their economic policies. Wade focused on the Trade-related Aspects of Intellectual Property Rights (TRIPS), Trade-related Investment Measures (TRIMS), and General Agreement on Trade in Services (GATS), all shepherded by the WTO. These agreements shrunk development space by binding developing countries into particular policies. Further research demonstrated that the WTO had shrunk development space for developing countries, and that the effect was not only limited policy choice but also a more inconsistent and tense relationship with IGO procedures (DiCaprio and Gallagher 2006). Recent work has traced how other IGOs, notably the IMF, has shrunk development space through the application of loan conditionality (Kentikelenis et al. 2016), including a reduction in bureaucratic quality in states 
subject to structural conditions (Reinsberg et al. 2019). Development space has narrowed despite the IMF and World Bank's expressed aim to provide its member states with more policy flexibility (Broome 2015; Güven 2018).

Our interest in development space is on how managerial trends in IGOs lead to changes in professional work practices that, in turn, shape how policy options are formulated, assessed, and implemented. The world-cultural frames that have promoted abstract managerialism have led to micro-level changes in how IGO work is considered and conducted. Changes at this level then lead to a convergence and narrowing of how IGO work is done, which shrinks the development space and affirms abstract managerialism as legitimate in world society. Our logic is therefore:

\section{MACRO MICRO MACRO \\ Abstract Managerialism $\quad \rightarrow \quad$ Change in IGO Work Practice $\quad->\quad$ Shrinking Development Space}

Here we focus on the micro element in this chain, via interviews and focus groups with IGO staff. Other studies have pointed to the external pressures on staff in IGOs, especially from neoliberal policy ideas (Chorev and Babb 2009) and how staff use their professional position within bureaucracies to counter or modify them (Chorev 2013). Our interviewees suggest that consultants are constraining development space, in part because the logic of consultancies is that there is a high premium on getting future contracts, which means that policy recommendations should not "rock the boat" and conform with mainstream policy approaches.

Elements of managerial trends and the use of consultants have been identified in recent literature but not brought together. For example, Momani (2017) has identified how global management consultants positively frame claims to understanding 'Big Data' and forecasting to simplify uncertainties into "actionable items" for governments and IGOs. Seabrooke and colleagues have studied how consultants are used by IGOs and INGOs to legitimate their claims to authoritative knowledge as well as how they are used in internal management strategies (Seabrooke and Nilsson 2015; Seabrooke and Wigan 2015; Henriksen and Seabrooke 2016). Daniel Béland and others have pointed to how heavily reliant IGOs are on consultants for policy diffusion, such as in their case on conditional cash transfers where the World Bank and Asian Development Bank "hired experienced international consultants not only to promote the idea but also to design, fund, and implement the programmes" (Béland et al. 2018: 14). Similarly, Bhatt's 
(2018) research on the Millennium Challenge Corporation, tasked by the US Millennium Challenge Account with a new global development finance program, developed governance techniques where consultants and Kennedy School experts were in control while local colleagues acted as data providers (Bhatt 2018: 167).

Park's (2017) study on IGOs' treatment of "project affected people” demonstrates how norm change within IGOs is supported by affirmations from external consultants who influence evaluation and review processes to promote empowerment and right-based audits and assessments. Broome and Quirk (2015) also find that consultants play an important role in narrowing how governance benchmarks are created and perpetuated, through creating authoritative assessments of both the substance and the conduct or implementation of policy. The rise of 'management talk' in IGOs has also been identified. Analyzing the language used in World Development Reports over time, Moretti and Pestre (2015) find that there is a shift in how the World Bank describes development and its role in it from a focus on describing the national economy and the scope for policy intervention, to generic determinants of growth and global best practices.

Research in organization studies has identified the power of consultants over governance practices in administrations. In particular, Sturdy and colleagues have detailed how consultants act as gatekeepers for practices within organizations and brokers between them, developing a "neo-bureaucracy" form of managerialism that changes how administrators govern (Sturdy and Wright 2011; O’Mahoney and Sturdy 2015). For Sturdy, Wright and Wylie (2015) the managerial trend towards consultancy encourages "marketized careers", the restructuring of politics around client relationships, and the use of "managed improvisation" around abstract management principles. Boussebaa and others have discussed how globally-active consultancies shape the distribution of knowledge between North and South (Boussebaa et al. 2012). Consultants from global professional service firms replicate and even accentuate neo-colonial power dynamics (Boussebaa 2017).

We contribute to this new literature on consultants and managerialism in the international political economy by highlighting how these trends are being filtered through IGOs, an organizational type normally assumed to represent a bureaucratic vocational model of public service at the international level. Our findings on how IGO staff perceive challenges from managerial trends is important is redressing this assumption. To give more detail on how this 
general trend is changing different IGOs we provide evidence from a range of IGOs concerned with development issues.

\section{Abstract Managerialism and the Market for Skills in IGOs}

Most studies on intergovernmental organizations focus on topics such as funding patterns (Reinsberg et al. 2017), bureaucratic forms (Barnett and Finnemore 2004), norm institutionalization (Park and Vetterlein 2010), rational design (Koremenos et al 2001), and cooperation with other organizations (Johnson 2016). While these features of IGOs are obviously important, they tell us less about how IGOs work cultures may change from influences on the organization, or what type of expertise and qualifications are deemed important to advance IGOs' strategies. From this view IGOs are bureaucracies that embody rational-legal authority that function well due to their capacity to breakdown tasks and assign them to offices best equipped to deal with them. Barnett and Finnemore draw directly from Weber's view of bureaucracy as their conceptual building block for studying IGOs, viewing bureaucracy as a consequence of "unfolding" rationalizations in modernity, following a drive for administrative efficiency and rational-legal authority (Barnett and Finnemore 2004: 18-21).

Recent scholarship has demonstrated systemic changes across a range of different IGOs and also changes in types of actors engaged global governance (Lall 2017). Abbott, Greene and Keohane (2016) show a significant rise in what they call "private transnational regulatory organizations", which co-exist with traditional IGOs. Theirs is an ecological perspective focused on organizational survival. Hannah, Ryan, and Scott (2017), Eagleton-Pierce (2018), and Margulis (2018) have demonstrated how lesser known IGOs can bond with INGOs on what constitutes expert knowledge to resist policy scripts imposed by dominant IGOs. This aspect of IGO functioning is lost if we treat them as bureaucratic entities whose formal-legal character shields them from managerial trends. That is: we lose out on an account of how IGOs, and other actors, may coevolve and be transformed in a manner that has as much to do with an organization's internal features, as it does with the shared institutional environment in which they all operate.

Abstract managerialism may be a central feature in such circumstances. We borrow from Meyer and Bromley a focus on the macro-cultural trend of managerialism, but we want to capture how this macro-cultural trend shapes how core tasks are performed. World Polity scholars tend to agree that the common form of bureaucracy is a consequence of rationalization and modernity 
(Meyer and Jepperson 2000), producing similarities in organizational form while divergence in practices (Henisz, Zelner, and Guillén 2005). Bureaucratic form is not set in stone. It changes with world cultural frames, as does the policy content and program management that follows from conflicts between professionals and political representatives in IGOs (Kentikelenis and Seabrooke 2017).

Important elements of the World Polity framework are that professionals are 'enactors' of world cultural frames, playing out roles that enact policy scripts, and that international organizations are the organizational embodiment of world cultural frames (Hironaka 2014). For theories of IGOs that view them as bureaucratic entities, the dominant professionals are international civil servants. It is no coincidence that analyses of IGOs that treat them as bureaucratic entities highlight the role of civil servants and their technical expertise as the professional bearers of the bureaucratic form. Barnett and Finnemore note that "A bureaucracy's autonomy derives from specialized technical knowledge, training, and experience that is not immediately available to other actors" (Barnett and Finnemore 1999: 708). There is a lot at stake in whether IGOs are in fact dominated by international civil servants or whether the enactment of policy scripts is coming from other professional models for the management and production of knowledge and expertise. We have some insights already here on scientific and practice communities as enactors. Ernst Haas and others working on epistemic communities have established how external scientific communities of "like-minded professionals" can influence IGOs through INGOs that have "consultative status" and are on expert panels (Haas 1990: 40). More recently, the work on 'international practices' has highlighted how experts and professionals create shared standards for competent actions (Adler and Pouliot 2011; Sending and Neumann 2011), including among project managers (Barnett 2018). Here our focus is on how enactors engaged in IGO work includes not only IGO staff but also consultants hired from a market for expertise. These consultants have been empowered by transnational managerial trends that favor particular forms of rationalization in how IGOs should develop policies and programs.

Work in the sociology of professions is helpful in this regard, as it suggests that professionalism is a 'third logic' that is distinct from bureaucracies and from markets (Freidson 2001). In this conception, professionalism is independent of the organization in which they work: they work towards goals they value, which have been given to them through formal training and belong to professional associations (Abbott 1988). The imposition of professional logics onto 
sectors, such as charities, has also been of interest (Hwang and Powell 2009), as has the reconstitution of action via formal professional associations into networks engaged in making boundaries around particular issues (Liu 2018). Recent research on the transnational sociology of professions suggests, for example, that professionals who are transnationally active, as with those working for IGOs, increasingly work towards organizational values rather than occupational values; that a common way of working across different national contexts is more important than how someone was trained (Faulconbridge and Muzio 2011; Seabrooke and Tsingou 2015; Henriksen and Seabrooke 2016). Studies of how transnational professionals create networks of influence to become 'epistemic arbiters' over what is appropriate policy knowledge have covered issues as diverse as accounting, taxation, shadow banking, health and population policy (Seabrooke 2014; Sending 2015; Thistlethwaite and Paterson 2016; Ban et al. 2016; Eskelinen and Ylönen 2017; Holzscheiter 2017; Hearson 2018). Research on intergovernmental organizations has also pointed to how homophily among professionals working in IGOs is important for how they think about policy design and program implementation (Chwieroth 2015; Sharma 2013; Nelson 2014) as well as how issue ecologies' form among professionals in and across IGOs (Block-Lieb and Halliday 2017; Stone 2013). By focusing on professionals, we aim to shift focus from organizational form and the role of donors to capture changes in IGOs' norms and practices, as perceived by their own staff.

\section{Interviews and Focus Groups}

To obtain an understanding of the micro-processes supporting macro-cultural trends in managerialism among IGOs we conducted 25 interviews with policy and human resources staff from a wide range of IGOs, as well as three focus group sessions with an additional 24 people attending. The IGOs chosen represented a mix in terms of size and staffing, as well as our access to managers and staff. Our particular focus was on the International Monetary Fund (IMF), the United Nations Development Programme(UNDP), the World Health Organization (WHO), and the World Bank Group. In addition, we also conducted interviews with private firms involved in the recruitment of international professionals, such as DEVEX, who hire for IGOs, INGOs, national aid agencies, and NGOs. Interviews were also conducted with consultants to the above organizations.

In talking with the IGO staff we stuck to a series of interview research themes in order to have comparable findings. Box 1 lists the key research themes. 
Box 1. Key Interview Research Themes

1. To what extent are consultants used in the work of the organization?

2. Are consultants hired to fill skill gaps or for specialist expert knowledge?

3. How are consultants identified and selected?

4. Do consultants work in staff teams or independently?

5. What is the effect of consultants on internal work organization and content?

6. Is there pressure from stakeholders to the organization to hire consultants for particular kinds of work and/or in particular policy areas?

We also organized focus groups, called Case Study Integrity Fora, to discuss these changes and what they suggest for the role and functioning of IGOs. Three focus groups were conducted in New York in November 2013, Washington D.C. in April 2014, and Geneva in November 2014. The use of focus groups, a relatively new methodological technique to readers of this journal (Alford and Philips 2018, see also Stanley 2016), were designed to check the integrity of our findings. Participants were provided with a precis of the key themes and questions and were asked to reflect on these in advance. They were then presented with trends within and across IGOs studied, as well as a depiction of the consultancy market for professionals, and asked to comment (if they so wished). First, we present the findings from our interviews, and then turn to reflections from IGO staff on the use of consultants in the discussion that follows.

\section{The Market for Skills in Intergovernmental Organizations}

IGOs are in a new framework where the question "buy, rent, or build?" is prominent. As general managerial trends towards the use of consultants have diffused across different IGO organizational environments, we should expect variation in how they been transposed (Boxenbaum and Battilana 2005). Figure 1 below, plots the change in the hiring of consultants within the IMF, the World Bank, and the OECD. It indicates two key things: First, that there is high level of reliance on consultants at the World Bank, less so at the IMF, and even less at the OECD. Second, that there is a clear upward trend for both the IMF and the World Bank, with 
the former hiring consultants at a level of 20-30\% of its workforce, while the World Bank has increased its hiring of consultants significantly, by 2015 at around $50 \%$. Figure 2 provides only a snapshot of 2012-2013, as the UN does not have systematic data on the subject over time. It is drawn from a report from the UN's Joint Inspection Unit (JIU 2014: 7), and shows that a handful of UN agencies, funds and programs rely heavily on consultants - between $50-75 \%$ of the total workforce are non-staff personnel. More specifically, it provides data on the UNDP and the WHO, both of which were subject to further analysis through interviews and focus-group discussions.

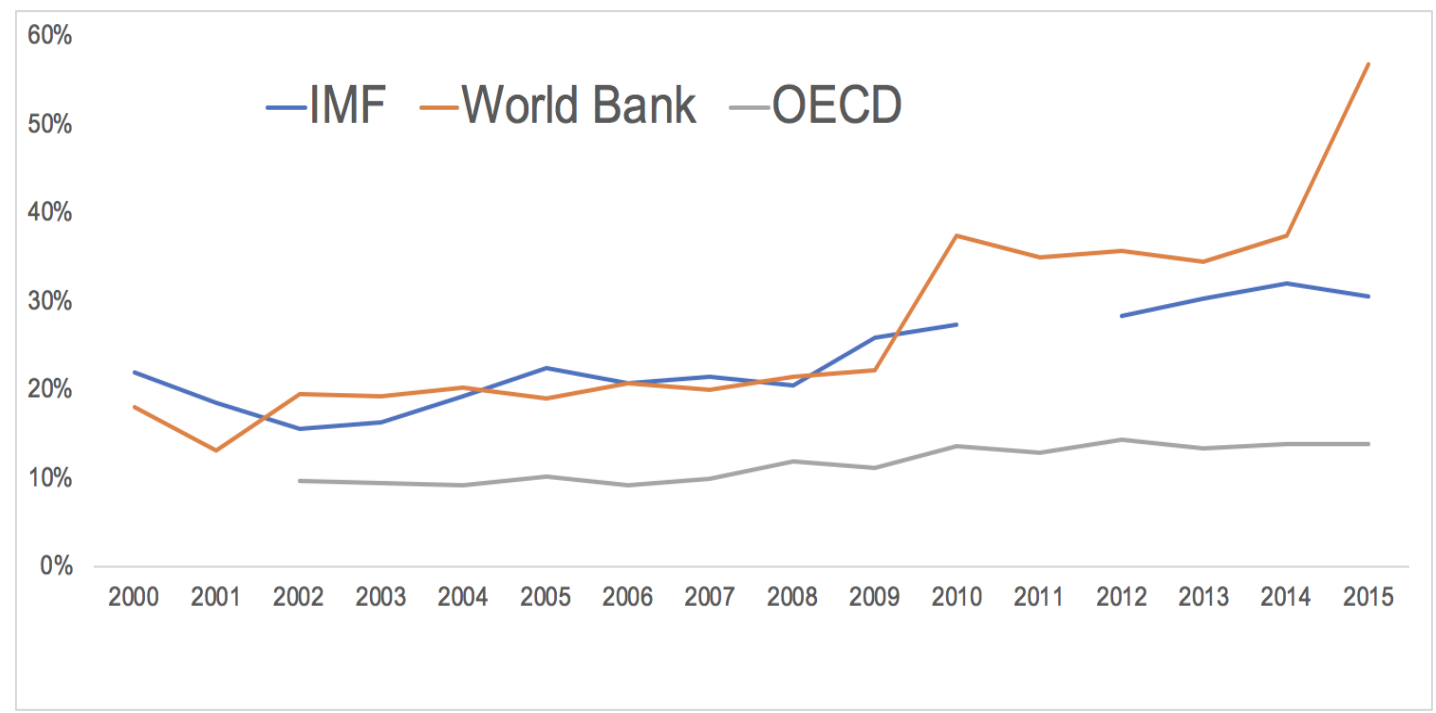

Figure 1. Consultancy expenditure relative to total staff expenditure

Source: Annual financial statements for the respective IGOs, 2000-15. World Bank numbers are from the IBRD arm of the group. 


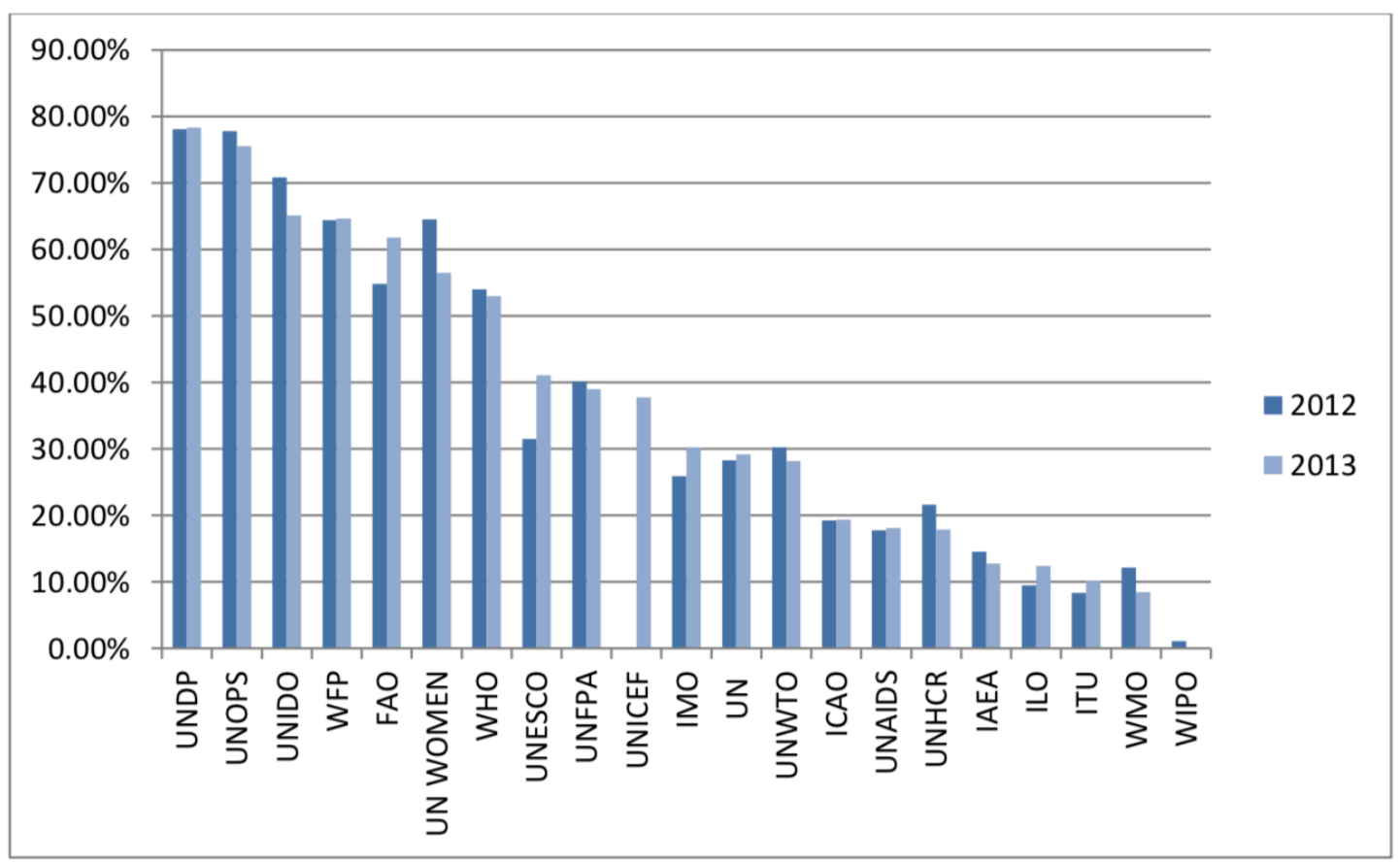

Figure 2. Non-Staff Personnel as \% of total workforce in UN System

Source: United Nations Joint Inspection Unit, 2014.

UNDP has the highest level of use of non-staff personnel, including consultants, at around $75 \%$. For WHO, the figure is slightly above 50\%. For the World Bank and UNDP the use of shortterm consultants differs according to a demand for specialist professional skills or whether the consultants are replicating professional skills already present in the IGO. For example, the hiring of short-term 'boutique' consultants in the UNDP was viewed by policy staff as a matter of technical capacity and convenience - that hiring permanent staff takes too long and emergencies and crises require immediate deployments, with potential consultants pre-vetted by the relevant department. ${ }^{2}$ In this context short-term consultants do not to pose a threat to permanent staff. We were told that $95 \%$ of staff hired by the UNDP are employed for their programming profiles, including running project teams. ${ }^{3}$ The JIU report found that close to fifty per cent of the people surveyed for its review on the use of consultants answered that consultants performed managerial tasks (JIU 2014: 24).

In the case of the UNDP, departments run their own rosters for hiring consultants, placing great emphasis on professional esteem and trust in the filling of skill gaps. One UNDP staff member noted that $90 \%$ of consultants hired had worked in the UN system previously and 
that the use of consultants was demand driven from country offices. ${ }^{4}$ This treatment of shortterm consultants is in strong contrast to the World Bank, who actively seek to hire staff on the assumption that the market for interesting work goes hand in hand with pay incentives that sort the wheat from the chaff. While the World Bank also has a decentralized search system that relies on each manager to have their own network and resources for some consultants, it also has 'Talent Search' and 'Executive Search' sections to hire, respectively, professionals and senior management. ${ }^{5}$ One UNDP staff member noted that they encouraged hiring consultants who had worked for the World Bank, since they were a 'source of learning' on best practices, while another noted that while it was a typical World Bank practice for staff to leave and form their own consultancies, this was uncommon in the UNDP. ${ }^{6}$ This difference between the World Bank and the UNDP suggest a market-based hierarchy of consultancy communities linked to IGOs.

The IMF hires consultants as experts on particular programs to fill skill gaps in the execution of programs that stretch the professional skill set available from the permanent staff (Seabrooke and Nilsson 2015), primarily in surveillance and the roll-out of policy reforms. The OECD uses short-term consultants but is actively seeking to minimize their use from a perception that they cannot compete with US-based IGOs on remuneration, and from the view that consultants can create instability among work teams. ${ }^{7}$

From the IGOs interviewed the UNDP is the most constrained - externally through its reliance on earmarked funding, and internally via established rules and ideals about the mandate and goals of the UNDP. This creates a difficult environment for professionals who identify more strongly with the 'consultancy community' than with the UNDP's ideological goals. Staff from the UNDP stressed that consultants hired should have knowledge of the interest groups and political economy' of the country or region they are working in, and that this was prized at the UNDP but occurring less, and that other IGOs, such as the World Bank, have no problem sending consultants from "Nepal to the Ukraine". A former UNDP consultant commented on the hostility towards consultants in the organization by noting that consultants have to use the visitors entrance even when working for substantial periods of time, including the securityrelated annoyances that accompany that status. ${ }^{9}$ The market for skills for IGOs also involves private recruitment firms that specialise on the INGO, NGO, aid agency, and IGO market. Lead among them is DEVEX, the "largest provider of recruiting and business development services for global development”. DEVEX boasts over 600,000 professionals engaged with its services with, at the time of writing, over 4,500 jobs and 15,000 tenders actively posted on their 
recruitment and funding system. The most common forms of placement are Evaluation Specialists and Business Development Specialists. ${ }^{10}$ As commented to us by a UNDP staffer, IGOs are "now competing with NGOs, private consultancies, etc., it's no longer just northwestern European civil servants" in the job market. ${ }^{11}$

To assess how abstract managerialism trends are changing IGO work practices we asked interviewees about how staff are remunerated, evaluated, hired, the relationship between permanent staff and consultants, and if having a consultancy position is a gateway to employment in an IGO. These factors reflect "abstract managerialism" as many of these trends come from a transnational professional cultural environment that is rooted in the private sector and more at home with global professional service firms than our typical image of IGO bureaucracies.

\section{Pay Systems and Performance Scorecards}

IGOs differ in the emphasis within their pay systems for permanent staff, with some favoring merit pay systems, while others pay staff on incremental scales based on tenure in the organization. These pay differences obviously have implications for how transnational professionals consider the IGOs and the incentives presented to work for them. The IMF and World Bank have merit or performance pay systems, with the World Bank managers operating a 'merit matrix' to assess salary ranges. ${ }^{12}$ Professionals seeking to work on development projects with the UNDP or World Bank know that the latter pay much better, in part as a reflection of pay for the permanent staff. The lower pay for short-term consultants does push professionals towards the World Bank and leaves the UNDP with less well-remunerated consultants. From our interviews, this can be seen as a strategy from the UNDP to reduce reliance on short-term consultants, to not attract those seeking higher pay, and to place indirect pressure on those above to loosen the purse strings on the permanent staff budget. Other UN agencies have taken the opposite approach, offering high pay for short-term consultants to cherry pick specialist professional skills. In a parallel to developments in the corporate world (Kang and Yanadori 2011), IGOs engagement with performance pay reflects attempts to gain credibility among its own staff and perceptions of the market for professional skills, in addition to the actual bottom line in what IGOs can provide within budget constraints. There are also serious costs to this managerial strategy. A former UNDP consultant noted that "merit pay is a killer in the UN system, because it kills programming and institutional memory, creating pressure to ascend in early career and then slow down to do interesting work and avoid boring meetings". ${ }^{13}$ Within 
the UNDP the absence of a strong merit pay system means that staff ascend in their careers by having "more stripes on your arm plus big budgets", leading to contention over who is promoted on the basis of the capacity to "make a deal" rather than field and program experience. ${ }^{14}$

On the use of performance scorecards and performance management, the forerunner among IGOs has been the World Bank, with a long history of being more 'managerial' than its peers. The sharpest contrast is IMF where performance management has been largely qualitative and resisted by the staff. ${ }^{15}$ For the IMF the timing of adjustment programs and long periods between the introduction of new policies and actual success, as well as professional incentives to spend time on academic research (Momani 2005), are the reasons why assessments are soft. This contrasts to World Bank assessments of project completion. The creation of scorecards, such as Accountability Scorecards, was linked in interviews to a need to respond to Corporate Social Responsibility, another trend coming from transnational managerial norms.

All of the IGOs studied have performance scorecards to which professional staff must respond. General managerial trends are reinforced by the Association of Human Resource Managers in International Organizations (AHRMIO) in Geneva, a body with more than 60 IGOs as members that facilitates the mutual training of human resources staff in IGOs, primarily through the Wharton School of the University of Pennsylvania. While the World Bank, in particular, is viewed as the trendsetter but not in the AHRMIO, all other IGOs interviewed for this study were members. A review on human resources issues for AHRMIO's tenth anniversary noted that 'hot button' topics were leadership and talent management, and that IGOs, INGOs, governments and firms are now all "looking for the same people" regardless of their professional training: those who know how to manage (CCL/AHMRIO 2010: 19). During interviews the blue AHRMIO-Wharton School folder was frequently seen in the offices of Human Resource Management staff. The extent of joint training among HR staff suggests strong isomorphism despite significant differences in how the IGOs are funded, governed and the professional diversity of their staff. Even the European Investment Bank, which is "shy of management consultants from bad experiences in the past" and affirmed the identify of their staff as international civil servants, ${ }^{16}$ was an active participant in these training networks.

The introduction of performance and talent management systems marks a shift from viewing professionalism as an occupational value - senior managers entrusting professionals to apply their specialist skills and abstract knowledge in a manner they see fit - to seeing professionalism via organizational performance. At the time of the interviews, the UNDP 
Director of Human Resources had recently been hired from Ernst and Young, where he was in charge of their global office. His task at the UNDP was to introduce private sector thinking on staff management and to assess the best means of doing so - including the active use of scorecards. His view was that the UNDP had a serious issue with a lack of staff turnover that led to a lack of market expertise. In this context permanent staff's benefits were viewed as "golden handcuffs" for talent development. ${ }^{17}$

\section{Co-Working and Employment Gateways}

Professional practices within IGOs may change significantly if permanent staff work alongside consultants who belong to a transnational professional culture rather than an IGO bureaucracy. In the case of the IMF the hiring of consultants occurs in specialist areas, such as fiscal experts on particular regions and countries. Interviews with IMF staff stress how while the Fund is known for operating according to a clear hierarchy and that within it there was significant 'turf protection' on information and strategy among the permanent staff, short-term consultants were making the IGO more flexible and responding to a senior management desire for "fresh blood". ${ }^{18}$

At the World Bank there is a separation between Extended Term Consultants, who are hired for 12 months and up to 24 months, and Short Term Consultants based on fees with no benefits a work period of up to 150 days. The World Bank's use of Short Term Consultants has increased as a consequence of budget flexibility needs, since these costs are moved over to the operational expenses rather than on the staff budget. ${ }^{19}$ For the World Bank contracted shortterm staff frequently work in teams with permanent staff on an ongoing basis. In the UNDP the story is mixed, with most consultants providing specialist skills, while for those with desired, or overlapping professional skills, UNDP staff engaged in knowledge management emphasized the importance of creating a 'buddy system' where knowledge is provided in addition to the formal contracting task. ${ }^{20}$ Here is a dynamic more commonly seen in the legal profession, with larger law firms providing 'free' services to retain clients, also reflecting the importance of trust networks rather than a purer market-driven conception of skills provision.

As for permanent staff leaving the IGO for a period to acquire new skills, the most prominent example is the IMF's 'Leave Without Pay in the Interests of the Fund' (up to 24 months with pension paid, frequently approved up to 36 months) and Leave Without Pay for Personal Reasons' (up to 48 months with no pension) that must be cleared by an External Assignment Committee, with departmental support following staff submission of a business case 
for the leave. A search in the IMF archives indicated that this practice has been occurring at least since $1984 .^{21}$ Such leave was granted for appointments such as acting as economic advisors to Prime Ministers, central banks, and economic ministries of member states. It was also used for engagement with financial markets.

In general, there is also a trend towards valuing two particular concepts among the professionals hired, as well as permanent staff: talent and mobility. The notion of professionals as 'talent' is particularly prominent in IGOs based in the US, which are surrounded by substantive consultancy communities where talent is linked to a combination of formal training and diverse experience (Thrift 2008). The notion that staff should be mobile is based on a similar logic, with some IGOs instituting compulsory mobility programs among their staff. The idea here is that long-term permanent staff who are not mobile are less competitive and not able to bring in lessons from the outside world and the private sector. Talent contrasts strongly with vocation as a key property for a professional to have to perform her job well in a bureaucracy. Similarly, in contrast to the view that the individual bureaucrat cannot squirm out of the apparatus into which he has been harnessed' (Weber 1978: 987-988), mobility is now prized as a way of keeping staff relevant. Many interviewees discussed a trade-off between the need for diverse experiences among those hired and the widespread loss of institutional memory within IGOs.

Within the consultant community providing professional services to INGOs, aid agencies, and IGOs, it is common for a one-year contract to be offered, and not uncommon for transnational professionals to leave for better prospects, creating incentives to demonstrate short-term performance (Cooley and Ron 2002). ${ }^{22}$ The issue of 'short-termism' was raised many times in focus groups as a key concern in how IGO work is increasingly conducted. From interviews with the UNDP and World Bank it is clear that working on short-term contracts or as consultants is viewed as a gateway to permanent employment. This is particularly the case for the World Bank where the notion of a 'golden ticket' is prominent, that being a permanent member of the World Bank leads to excellent work conditions (which are also changing under marketization). From those interviewed there was a different perception at the UNDP, mainly due to the lower salary levels. In the IMF staff are commonly hired through the Economist Program, while the World Bank has its Young Professionals program, all of which target MScs and $\mathrm{PhD}$ from elite universities (Nelson 2014). The flow of staff from consultants to permanent staff may also move in the other direction. At the World Bank, the extensive use of Short Term 
Consultants has had an impact on attitudes for hiring permanent staff, including a drive in 2009 to change the employment framework away from permanent contracts to renewable contracts with terms of up to five years. ${ }^{23}$ In interviews with recruiters, it was noted that there is a trend for professionals with exclusively private sector backgrounds to enter work for IGOs and NGOs. ${ }^{24}$

The picture that emerges is one where IGOs are nominally bureaucratic but substantively institutional ecologies that are part of a transnational professional culture. This has important implications for how IGOs treat the issues they work on, and how they establish the boundaries of their work. Akin to the private sector, the prevalence of trends towards a consulting culture, especially around the World Bank, leads to the selection of professionals who can signal a capacity for rationality and organization at the international level, including use of best practices and standard reporting formats (Armbrüster 2004). Similarly, the certification of project managers is one trend, especially with 'program development' within IGO mandated projects. Associations such as the International Association of Project Managers (IAPM) were noted as important and there is increased demand for professional evaluation specialists who operate internationally. Most of the consultants hired have a mix of technical expertise and business and program development experience, clearly adopting a view of professionals as those who can operate across different organizational contexts. ${ }^{25}$

\section{Effects on IGOs' Role and Functions}

What, then, are the effects of these trends towards managerialism within IGOs on their role and functioning? Managerialism as expressed here does not alter the bureaucratic form of IGOs, but it does transform how these organizations operate and how they relate to member states. We highlight two effects of this transformation. The first is that the gateway function of IGOs to stop or support new policy ideas shifts from within these organizations towards global best practices and benchmarks, the contents of which evolve through discussions in transnational networks of professionals that cut across distinct IGOs. The second is that IGOs relate to member states as clients that are in need of skills. This is, in part, explained by the relative decline of established norms of civil servants in a bureaucracy, and the increased importance attached to norms of producing solutions that clients demand. 
The WHO, IMF and the World Bank are all - to varying degrees - characterized by a uniformity of their knowledge base in either public health/medicine or in economics. Homogeneity among the staff has been emphasized in studies of staff in these IGOs, be it from a commitment to a public ethos (health) (Chorev 2013) or common forms of training and worldviews (economics) (Chwieroth 2015; Nelson 2014). Not so with UNDP, whose key claim to expertise has been extensive field presence and exclusive access to national governments in the developing world. The emergence of managerialism has therefore had a different effect on the UNDP than the other organizations. The fault line is less between professionally based expertise and the specialized skills of consultants, but between skills linked to projects and their management and implementation, and the ability to mobilize "local" knowledge and help national governments increase their own development space (Murphy 2006). The model at the UNDP used to be one where its civil servants - as experts on "international" issues with local knowledge - were in a position of privilege from which to advise developing countries on issues (Sending 2015). The culture associated with this model has morphed into one where the claim to expertise is not so much from being able to tap into both local and international knowledge. Rather, it is one that mobilizes skills and tools from the global marketplace to tell developing countries what they need to do to cope with globalization, which we interpret as a contraction of development space. As UNDP Administrator Mark Malloch-Brown noted early in his tenure:

\footnotetext{
We need to be a kind of McKinsey for the developing world: advising on the issues people have to address, reforming the public sector, and developing a new form of governance in developing countries. ${ }^{26}$
}

The vision set out in the early 2000s, and the managerial and strategic changes it resulted in, has transformed the organizational culture at the UNDP, where, as one staffer put it, "old political norms and the marketplace for ideas" create friction. ${ }^{27}$ The focus on experience from the "field" (in developing countries) that used to be seen as important is now less so, with one UNDP participant in a focus group noting that time in the field was increasingly seen as less important for career advancement in the UN system. ${ }^{28}$ The shift towards finding more managerial and universal solutions for developing countries was also stressed.

The traditional organizational culture at UNDP drew heavily, as one interviewee put it, on the idea of civil servants having "a good mind", emulating the British model that also shaped 
the first decades of both the League of Nations and the UN (Sending 2014). This is now challenged by how the UNDP is "competing with NGOs, private consultancies etc.", a trend that is compounded by the importance of consultants in key aspects of UNDP operations. ${ }^{29}$ The role of UNDP is now much more, in keeping with this trend, heavily focused on mobilization for and advice on reaching the Sustainable Development Goals (SDGs). As one focus-group participant with long experience from the UN noted, "there has been a change from the professional judgment of people in the field to evaluation systems". ${ }^{30}$ This development ties in with another, that the UNDP is experiencing a "loss of reflexivity", with the organization being seen more as a "lapdog" of donors. ${ }^{31}$ The rise of managerialism at the UNDP in the 1990s is closely linked to donors demanding more effective, efficient programming and increased fiduciary accountability. The UNDP responded by introducing different versions of logical framework ('logframe') approaches and results based management (Ortiz and Tang 2006). Combined with the more recent trend towards focusing on policy advice linked to the SDGs, it has re-positioned the UNDP's role to serve, as noted in its 2018 Strategic Plan, as a "trusted partner" that is "nimble, innovative and enterprising - a thought leader that succeeds in taking and managing risks" (UN 2017:2).

There is arguably less friction between staff and consultants at the World Bank. This is due to its organizational culture, being more open to consultants who bring in expertise and skills that fits within the modus operandi. This is largely due to the project management orientation of the Bank, which is similar to the UNDP but better funded. Even given this affinity between a project-based IGO and consultant project managers, we can identify a change in how the Bank relates to both member states and consultants. The change is from one of in-house expertise as the basis for policy advice to one where global benchmarks serve as codified best practice within which the Bank provides advice. An interviewee suggested that the Bank's change from being a "Knowledge Bank" from the late 1990s towards a "Solutions Bank" from 2012 signalled an overarching objective of creating demand for Banks services. This included a "global practice" stream whereby Bank staff could engage in joint training with potential clients from borrowing states. ${ }^{32}$ Consultants are heavily involved in determining what is considered best global practice. These global practices are then used to create demand for IGO services and are communicated to client states about what it means to be a modern state and a competent sovereign (Neumann and Sending 2010; Bartelson 2014). Taken together, the change from 
anchoring policy within the IGO bureaucracy to codifying it in best practices directed at a 'client orientation' constraints development space.

One source of constraint here is in how consultants establish the data infrastructure and reporting standards on what become benchmarks and market practices. The World Bank's Doing Business survey is an example where the IGO relies heavily on "bad science" from consultants to report on administrative processes, labor conditions, contract conditions, among many others, that are then used to create an index of the ease of doing business in various states for would-be investors (Broome et al. 2018). A further example can be found in microfinance, where the World Bank used consultants to establish the market infrastructure. This included accounting and reporting standards, the technological platform for investors to trade with location institutions, as well as the indicators used in social impact assessments. The establishment of Microfinance Information Exchange market is a clear example where consultants were used for program design and implementation to guide investors and make microfinance 'calculable', in part by including poverty indicators that became largely cosmetic (Henriksen 2013).

Within the IMF the use of consultants has been to fill expertise gaps, or also to bolster its credibility on particular policy scripts (Halliday et al. 2009: 20). An example can be found in the IMF's Financial Sector Assessment Programme, which provides evaluations of the health of financial systems and, since 2013, is mandatory for 29 member states with systemically important financial sectors. This program has been important in the IMF's expansion of activities from macroeconomic surveillance to also financial systems surveillance (Vetterlein and Moschella 2014: 154). The history of FSAP includes a change in the profiles of those externally hired to assist with country assessments, from consultants with similar profiles to IMF permanent staff to those more associated with senior advisory roles in the public and private sector; those with more gravitas (Seabrooke and Nilsson 2015). The increase in the use of consultants has been, in part, from prominent member states who have asked for the staffing of FSAP missions to include consultants with recent market-based skills, because they assume that IMF technocrats may not have the relevant expertise. ${ }^{33}$ With a combination of senior consultants and powerful member states pushing for their interpretation of how financial systems should be governed and surveilled, FSAP adopted principles that were strongly informed by American and British views on microprudential supervision and "light-touch" regulation (Moschella 2011: 123). They were also heavily based on the creation of composite quantitative measures, especially Financial Soundness Indicators, that were used as 'soft' tools for policy dialogue (Seabrooke 2012: 501). 
While these ideas have since been challenged by macroprudential oversight frameworks (Baker 2018), the use of external consultants for the assessment of financial systems through indices and benchmarks has continued. As has the trend towards hiring particular external consultants, with a senior IMF staff member affirming in one of our focus groups that the IMF "roster of consultants is shifting to market-based expertise". ${ }^{34}$ This roster is also important not only for surveillance but for policy roll-outs. On tax reform, for example, it is well-established that the IMF used consultants to present a common view to developing states that some policies are a “necessary modernisation” that is essentially technical rather than political (Fjeldstad and Moore 2008: 241; see also Ban 2016: 176-7; Kentikelenis and Seabrooke 2017). The same can be said for insolvency regulations, where the IMF also relied on particular consultants to affirm its expert authority on policy changes and to provide hands-on drafting of laws in countries (Halliday and Carruthers 2009: 307). In short: the IMF hires consultants to affirm its expert authority, which it self-perceives as not only coming from their highly trained economists, but also from the gravitas of consultants selling their expertise on the market.

Finally, the World Health Organization has historically been characterized by a strong and uniform professional base - dominated by public health and medicine - at the core of its civil servants. The delegates at the World Health Assembly were typically from health ministries, consolidating the dominance of a health ethos, as expressed in the goal of "Primary Health Care" (Hanrieder 2015: 100). However, the WHO lost its dominant position on global health matters during the 1990s, due to criticism of corruption and a 'socialist' bias from the US and others, and competition from other IGOs, such as the World Bank and UNICEF. From the late 1990s onwards, the WHO adopted managerialism, as expressed in a paradigm shift from seeing health as an end in itself, to seeing health and economic reforms as interwined (Chorev 2012). This reform was championed by Director General Harlem Brundtland from 1998 onwards, and it relied heavily on consultants to forge a new rationale for health investments within ministries of finance (Chorev 2013; Hanrieder 2015). Jeffrey Sachs headed the WHO Commission on Macroeconomics and Health (2001), which introduced new tools for measuring and justifying health investments as sound economic policy. For the WHO the trend towards abstract managerialism led to reform in the IGO by drawing on outside expertise from a different professional base (economics), as well as managerialism through quantifiable measures linking health directly to assessments of the so-called "burden of disease", as in the idea of "disabilityadjusted-life-year" (DALY). WHO staff used the emphasis on economic growth to boost funding, 
while at the same time "maintaining a focus on infectious diseases affecting the poor" and also developing better relations with the private sector (Chorev 2013: 654). This transformation has also resulted in consultancies becoming more important, with the traditional WHO civil servants, trained in medicine or public health, becoming less dominant. The new idiom of global health governance - organized around the economic rationale for health investment - is one that actors in the Global South have increasingly adopted as a way to be heard, with the effect of further institutionalizing managerialism (Chorev and Schrank 2017). This is something that international civil servants react against. In our focus groups WHO staff noted that consultants from global professional service firms "are agile, while we are moving in molasses" and that consultants are "constantly on the premises, providing solutions that are never implemented". ${ }^{35}$ We were also told that in the case of the WHO senior managers had a detrimental drive to find 'talent' rather than experienced policy and program staff, and that an “organization doesn't need 11 strikers on its team" ${ }^{36}$

\section{Conclusion}

In 1979 Meyer and Hannan argued that "the world as a whole shows increasing structural similarities of form among societies without, however, showing increasing equalities of outcomes among societies" (Meyer and Hannan 1979, 3, 13-15). This apposite observation touches directly on the issue of how managerialism shapes the infrastructure of global governance through IGOs. Our analysis has identified the micro-processes through which macro-cultural forms become manifest in IGO work practices, at least as considered by IGO staff. We should be cautious of not overstating the argument: we are not claiming that all IGOs, in all sectors, experience the same type of trend towards a reliance on consultants. While there is certainly a general trend there is also variation in how IGOs engage consultants.

We should also be careful not to overstate the importance of transnational professionals (Dezalay and Garth 2016), especially their independent agency (Scott 2008), in creating change in international organizations. But as enactors of world cultural frames, transnational professionals make claims to who should work on what issues, and who should be recognized as having authoritative expertise. What is clear is that IGO staff think there is a general change in work practice occurring among IGOs. International civil servants have traditionally been seen as the backbone of IGOs as bureaucratic entities that mirror the state, in no small part because they are seen as a particular type of professional group with a commitment to the bureaucratic 
ethos of formality and the application of expertise within a set of established rules. As we have seen above, consultants have become important to IGOs, and introduce a new ethos of operations, focused on marketable skills and the application of best practice honed from a global marketplace. This has at least two effects. The first is that there is a tension that cuts through IGOs, between "rules" and "performance", with professionals pitted against one another over the basis for professional judgement (experience and expertise v skills/talent and best practice). The second is how institutional memory is valued as a resource for policy development, especially if the gatekeepers of policy design and implementation have migrated from viewing IGOs as bureaucratic entities towards transnational professional networks. Transnational policy clubs also affirm the notion that policy knowledge is best found among those who move easily between public and private sectors (Tsingou 2015). In these settings consultants can exert significant amounts of influence by determining how best practice standard should be governed (Wright et al. 2012).

Another largely overlooked feature of managerialism is how it transforms the “publicness" of IGOs (Eriksen and Sending 2013). IGOs are not necessarily as "universal” as is often assumed, because they depend on voluntary, and earmarked, funding. This is compounded if the professional focus of those performing core tasks does not align with a conception of an international "public" but to viewing themselves as implementing agents following market dynamics. As we have documented above, IGO staff have serious concerns that IGOs' use of consultants depletes their autonomy, their memory, and compounds power asymmetries in the international political economy.

A further concern is that the rise of consultancies in IGOs has an effect not only for the expert work done by IGOs but also for their relative prestige and how they articulate the normative goals they aspire to. For example, if the more pro-market Bretton Woods IGOs are more highly esteemed by international civil servants and the consultant community - which our evidence suggests is certainly the case - then there may be less rallying around "human development” norms, which are more associated with the United Nations agencies (Thérien 2012). Managerial trends across IGOs then affirm the importance of 'seeing' and working like the World Bank in how they handle projects and conduct surveillance and policy roll-outs (Vetterlein 2012). This cements the dominance of the Bretton Woods institutions over the IGO landscape and the subordinate role of UN agencies, despite their more holistic treatment of issues such as poverty (Weaver 2008; Thérien 2009). States' perceptions of what IGOs have policy 
autonomy and expertise supports the view that the Bretton Woods IGOs, as well as new publicprivate hybrids, are superior to the UN agencies and should receive more attention (Lall 2017). The literature on principal-agent dynamics among IGOs would suggest that those less esteemed should change their behavior to narrow the gap between principal and agent preferences (Hawkins et al. 2006). UN agencies would then move towards more market-based expertise to assuage state interests and bolster their own claims to expert authority (Sending 2015). The further entry of consultants into the networks that form an IGO's 'policy nexus' would then be a logical consequence (Allan 2019).

The rise of abstract managerialism within across IGOs is important to understand because even if the formal bureaucratic forms have not altered, changes in work practices are important in how IGO staff, consultants, and member state representatives can articulate 'development space'. If there is a consensus among consultants hired by IGOs that there are only particular ways of developing policy scripts and evaluating programs, and this understanding belongs to the transnational consultancy community rather than to IGOs, then policy space has contracted. This contraction occurs through formal and informal means, as well as structuring the general environment for policy work. Practically it occurs through contract modalities that affirm the importance of 'work-to-contract' and short-termism, as well as the interoperability of solutions across organizational platforms. These logics inform how information on policies and programs is gathered and evaluated, including how successes and failures are recorded and communicated. Convergence within the professional environment on what is authoritative expert knowledge deepens the rationalizing effects of such work, which then legitimates the contraction of development space among the professional community, including among IGO staff. Further research is needed on interactions between transnational professionals and the international organizations such as IGOs, INGOs, and other hybrid bodies. While consultants may be enactors of roles according to dominant world cultural frames, rather than free-moving change agents, their collective effect is to change the politics of the possible for international organizations and their member states.

\section{Notes}

1. Mauro Guillén's 1994 study of the diffusion of management ideology and practice in the US, Germany, Spain and UK in the twentieth century suggests that new management techniques premised on efficiency and scientism can be diffused when there is: structural industrial change, international pressure, labor unrest, elite mentality, and support from professional groups. IGOs 
such as the International Monetary Fund and World Bank are at the forefront in generating all of these pressures.

2. Interview with UNDP program staff, New York, March 2012.

3. Interview with UNDP program staff, New York, March 2012.

4. Interview with UNDP program staff, New York, March 2012.

5. Interview with senior World Bank Human Resources staff, Washington D.C., March 2013.

6. Interview with UNDP Management Consultancy Team, New York, March 2012.

7. Interview with OECD program staff, by phone, May 2014.

8. Interview with UNDP Management Consultancy Team, New York, March 2012.

9. Interview with former UNDP consultant, Copenhagen, October 2012.

10. Interview with DEVEX Staff, Washington D.C., March 2013

11. Interview with UNDP Learning Specialist, New York, November 2013.

12. Interview with senior World Bank Human Resources staff, Washington D.C., March 2013.

13. Interview, former UNDP consultant, Copenhagen, June 2013.

14. Interview with UNDP Learning Specialist, New York, November 2013.

15. Interview with IMF Human Resources staff, Washington D.C., March 2012.

16. Interview with European Investment Bank Senior Staff, Luxembourg, June 2012.

17. Interview UNDP Director of Human Resources, September 2013.

18. Interview with IMF Human Resources staff, Washington D.C., March 2012.

19. Interview with senior World Bank Human Resources staff, Washington D.C., March 2013.

20. Interview with UNDP Management Consultancy Team, New York, March 2012.

21. Interview with IMF Human Resources staff, Washington D.C., March 2012. From an archival search in the IMF records it is clear that leave was commonly granted for advising central banks and ministries, as noted, commonly in the Middle East and Africa, but also, for example, Sweden. Leave to the World Bank is also not infrequent. 
32. Interview with World Bank program staff, Washington D.C., August 2014.

33. Interview with former Senior IMF staff, Washington D.C., November 2013.

34. IMF Senior Staff, Case Study Integrity Forum, Washington D.C., April 2014.

35. WHO Senior Staff, Case Study Integrity Forum, Geneva, November 2014.

36. WHO Senior Staff, Case Study Integrity Forum, Geneva, November 2014.

\section{Acknowledgements}

This research was presented at the 'Sociology of International Organizations' workshop as part of the American Sociological Association annual conference in Philadelphia, August 2018. We thank, in particular, Sarah Babb, Nitsan Chorev, Terry Halliday, Tine Hanrieder, Joseph Harris, and Alex Kentikelenis for their feedback. Thanks also go to Cornel Ban, Eva Boxenbaum, Martin Bæk Carstensen, Matthew Eagleton-Pierce, Lea Foverskov, Stine Haakonsson, Christian Henriksen, Lasse Folke Henriksen, Sam Knafo, and Eleni Tsingou for their suggestions. Our thanks also go to the reviewers for their constructive criticisms.

\section{Disclosure statement}

No potential conflict of interest was reported by the authors.

\section{Funding}

Seabrooke and Sending gratefully acknowledge financial support from the Norwegian Research Council grant 'The Market for Anarchy' (\#274740).

\section{Notes on Contributors}

Leonard Seabrooke is Professor of International Political Economy and Economic Sociology in the Department of Organization at the Copenhagen Business School, and Research Professor at the Norwegian Institute of International Affairs. His research currently focuses on transnational professionals, international organizations, activist movements, and consultancy communities on a range of politico-economic issues. He is co-editor of Professional Networks in Transnational Governance (Cambridge University Press 2017, with Lasse Folke Henriksen).

Ole Jacob Sending is Director of Research at the Norwegian Institute of International Affairs. His research focuses on changes in state sovereignty, the evolution of international organizations, the development of professional expertise, and the role of private actors in global governance. His most recent book is The Politics of Expertise: Competing for Authority in Global Governance (University of Michigan Press, 2015).

\section{ORCID}


Leonard Seabrooke: https://orcid.org/0000-0001-5581-3293

Ole Jacob Sending: https://orcid.org/0000-0003-4456-4708

\section{References}

Abbott, A. (1988) The System of Professions: An Essay on the Division of Expert Labor, Chicago: University of Chicago Press.

Abbott, K. W., J.F. Green and R.O. Keohane (2016) 'Organizational ecology and institutional change in global governance', International Organization 70(2): 247-277.

Adler, E. and V. Pouliot (2011) 'International practices', International Theory 3(1): 1-36.

Allan, B.B. (2019) 'Paradigm and nexus: neoclassical economics and the growth imperative in the World Bank, 1948-2000', Review of International Political Economy 26(1):183-206.

Alford, M. and N. Phillips (2018) 'The political economy of state governance in global production networks: change, crisis and contestation in the south african fruit sector', Review of International Political Economy, 25(1): 98-121.

Armbrüster, T. (2004) 'Rationality and its symbols: signaling effects and subjectification in management consulting', Journal of Management Studies 41(8): 1247-1269.

Baker, A. (2018) 'Macroprudential regimes and the politics of social purpose', Review of International Political Economy 25(3): 293-316.

Ban, C. (2016) Ruling Ideas: How Global Neoliberalism Goes Local, Oxford: Oxford University Press.

Ban, C., L. Seabrooke and S. Freitas (2016) 'Grey matter in shadow banking: international organizations and expert strategies in global financial governance', Review of International Political Economy 23(6): 1001-1033.

Barnett, M. (2018) Human rights, humanitarianism, and the practices of humanity', International Theory 10(3): 314-349.

Barnett, M. and M. Finnemore (1999) 'The politics, power, and pathologies of international organizations', International Organization 53(4): 699-732.

Barnett, M. and M. Finnemore (2004) Rules for the World. Ithaca: Cornell University Press.

Bartelson, J. (2010) 'The social construction of globality', International Political Sociology 4(3): 219-235.

Béland, D., R. Foli, M. Howlett, M. Ramesh and J.J. Woo (2018) 'Instrument constituencies and transnational policy diffusion: the case of conditional cash transfers', Review of International Political Economy, 25(4): 463-482.

Best, J. (2014) Governing Failure: Provisional Expertise and the Transformation of Global Development Finance, Cambridge: Cambridge University Press. 
Bhatt, J.D. (2018) 'Politics by other means: economic expertise, power, and global development finance reform', Doctoral Dissertation, Department of Sociology, Columbia University, Columbia University Academic Commons, https://doi.org/10.7916/D8184Q09.

Block-Lieb, S. and T. C. Halliday (2017) Global Lawmakers: International Organizations in the Crafting of World Markets, Cambridge: Cambridge University Press.

Boussebaa, M. (2017) 'Global professional service firms, transnational organizing and core/periphery networks', in L. Seabrooke and L.F. Henriksen (eds) Professional Networks in Transnational Governance, Cambridge: Cambridge University Press: 233-244.

Boussebaa, M., G. Morgan, and A. Sturdy (2012) 'Constructing global firms? national, transnational and neocolonial effects in international management consultancies', Organization Studies 33(4): 465486.

Boxenbaum, E. and J. Battilana (2005) 'Importation as innovation: transposing managerial practices across fields', Strategic Organization 3(4): 355-383.

Broome, A. (2015) 'Back to basics: the great recession and the narrowing of IMF policy advice', Governance, 28(2), 147-165.

Broome, A., A. Homolar, and M. Kranke (2018) 'Bad science: international organizations and the indirect power of global benchmarking', European Journal of International Relations 24(3): 514-539.

Broome, A. and J. Quirk (2015) 'Governing the world at a distance: the practice of global benchmarking', Review of International Studies 41(5): 819-841.

Broome, A., and L. Seabrooke (2012) 'Seeing Like an International Organization', New Political Economy 17(1): 1-16.

Center for Creative Leadership/Association for Human Resources Management in International Organizations (2010) 'Leadership \& Talent Development in International Organizations', Brussels: CCT.

Chorev, N. (2012) The World Health Organization between north and south. Cornell University Press.

Chorev, N. (2013) 'Restructuring neoliberalism at the World Health Organization', Review of International Political Economy, 20(4), 627-666.

Chorev, N. and S. Babb (2009) 'The crisis of neoliberalism and the future of international institutions: a comparison of the IMF and the WTO', Theory and Society 38(5): 459-484.

Chorev, N. and A. Schrank (2017) 'Professionals and the professions in the global south: an introduction', Sociology of Development 3(3): 197-211.

Chwieroth, J.M. (2015) 'Professional ties that bind: how normative orientations shape imf conditionality', Review of International Political Economy 22(4): 757-787.

Cooley, A. and J. Ron (2002) 'The NGO scramble: organizational insecurity and the political economy of transnational action', International Security 27(1): 5-39. 
DiCaprio, A. and K.P. Gallagher (2006) 'The WTO and the shrinking of development space', Journal of World Investment and Trade 7(5): 781-803.

Dezalay, Y. and B.G. Garth (2016) “Lords of the dance” as double agents: elite actors in and around the legal field', Journal of Professions and Organization 3(2): 188-206.

Eagleton-Pierce, M. (2018) 'Professionalizing protest: scientific capital and advocacy in trade politics', International Political Sociology 12(3): 233-255.

Eriksen, S.E. and O.J. Sending (2013) 'There is no global public', International Theory 5(2): 213-237.

Eskelinen, T. and M. Ylönen (2017) 'Panama and the WTO: new constitutionalism of trade policy and global tax governance', Review of International Political Economy 24(4): 629-656.

Faulconbridge, J. and D. Muzio (2008) 'Organizational professionalism in globalizing law firms', Work, Employment and Society, 22(1): 7-25.

Faulconbridge, J. and D. Muzio (2011) 'Professions in a globalizing world: towards a transnational sociology of the professions', International Sociology 27(1): 136-152.

Fjeldstad, O.-H. and M. Moore (2008) 'Tax reform and state building in a globalized world', in D. Brautigam, O.-H. Fjeldstad, and M. Moore (eds) Taxation and State Building in Developing Countries, Cambridge: Cambridge University Press: 235-60.

Freidson, E. (2001) Professionalism, the Third Logic: On the Practice of Knowledge, Chicago: Chicago University Press.

Guillén, M.F. (1994) Models of Management: Work, Authority, and Organization in a Comparative Perspective. Chicago: University of Chicago Press

Güven, A.B. (2018) 'Whither the post-Washington Consensus? International financial institutions and development policy before and after the crisis', Review of International Political Economy 25(3): 392417 .

Haas, E.B. (1990) When Knowledge is Power: Three Models of Change in International Organizations, Berkeley: University of California Press.

Halliday, T.C. and B. Carruthers (2009) Bankrupt: Global Lawmaking and Systemic Financial Crisis, Stanford: Stanford University Press.

Halliday, T.C., S. Block-Lieb and B.G. Carruthers (2009) 'Rhetorical legitimation: global scripts as strategic devices of international organizations', Socio-Economic Review 8(1): 77-112.

Hannah, E. H. Ryan, and J. Scott (2017) 'Power, knowledge and resistance: between co-optation and revolution in global trade', Review of International Political Economy, 24(5): 741-775.

Hanrieder, T. (2015) International Organization in Time: Fragmentation and Reform. Oxford: Oxford University Press. 
Harrison, G. (2001) 'Administering market friendly growth? Liberal populism and the World Bank's involvement in administrative reform in sub-Saharan Africa', Review of International Political Economy 8(3): 528-547.

Hawkins, D.G., D.A. Lake, D.L. Nielson, and M.J. Tierney (eds) (2006) Delegation and Agency International Organizations, Cambridge: Cambridge University Press.

Hearson, M. (2018) 'Transnational expertise and the expansion of the international tax regime: imposing “acceptable” standards', Review of International Political Economy 25(5): 647-671.

Henisz, W.J., B.A. Zelner, and M.F. Guillén (2005) 'The worldwide diffusion of market-oriented infrastructure reform, 1977-1999', American Sociological Review 70(6): 871-97.

Henriksen, L.F. (2013) 'Performativity and the politics of equipping for calculation: constructing a global market for microfinance', International Political Sociology 7(4): 406-425.

Henriksen, L.F. and L. Seabrooke (2016) 'Transnational organizing: issue professionals in environmental sustainability networks', Organization 23(5): 722-741.

Hironaka, A. (2014) Greening the Globe: World Society and Environmental Change. Cambridge: Cambridge University Press.

Holzscheiter, A. (2017) 'Coping with institutional fragmentation? Competition and convergence between boundary organizations in the global response to polio', Review of Policy Research 34(6): 767-789.

Hopewell, K. (2015) 'Multilateral trade governance as social field: global civil society and the WTO', Review of International Political Economy 22(6): 1128-1158.

Hopgood, S. (2006) Keepers of the Flame: Understanding Amnesty International. Ithaca: Cornell University Press.

Hwang, H., and W.W. Powell (2009) 'The rationalization of charity: the influences of professionalism in the nonprofit sector', Administrative Science Quarterly 54(2): 268-298.

Johnson, T. (2016). Cooperation, co-optation, competition, conflict: international bureaucracies and nongovernmental organizations in an interdependent world. Review of International Political Economy, 23(5), 737-767.

Kang, S.-C. and Y. Yanadori (2011) 'Adoption and coverage of performance-related pay during institutional change: an integration of institutional and agency theories', Journal of Management Studies, 48(8): 1837-1865.

Kentikelenis, A.E. and L. Seabrooke (2017) 'The politics of world polity: script-writing in international organizations', American Sociological Review 82(5): 1065-1092.

Kentikelenis, A.E., T.H. Stubbs and L.P. King (2016) 'IMF conditionality and development policy space, 1985-2014', Review of International Political Economy 23(4): 543-582. 
Kim, H.J. and J.C. Sharman (2014) 'Accounts and accountability: corruption, human rights, and individual accountability norms', International Organization 68(2): 417-448.

Koremenos, B., C. Lipson, and D. Snidal (2001) 'The Rational Design of International Institutions', International Organization 55(4): 761-799.

Lall, R. (2017) 'Beyond institutional design: explaining the performance of international organizations', International Organization 7 1(2): 245-280.

Liu, S. (2018) 'Boundaries and professions: toward a processual theory of action', Journal of Professions and Organization 5(1): 45-57.

Margulis, M.E. (2018) 'Negotiating from the margins: how the UN shapes the rules of the WTO', Review of International Political Economy 25(3): 364-391.

Meyer, J. W. and P. Bromley (2013) 'The worldwide expansion of “organization”, Sociological Theory 31(4): 366-89.

Meyer, J.W., and M.T. Hannan (1979) 'National development in a changing world system: an overview', in J.W. Meyer and M.T. Hannan (eds) National Development and the World System: Educational, Economic, and Political Change, 1950-1970, Chicago: University of Chicago Press: 3-16.

Meyer, J.W. and R.L. Jepperson (2000) 'The "actors” of modern society: the cultural construction of social agency', Sociological Theory 18(1): 100-120.

Moretti, F., \& Pestre, D. (2015). Bankspeak: the language of World Bank reports. New Left Review, 92(2), 75-99.

Moschella, M. (2011) 'Lagged learning and the response to equilibrium shock: the global financial crisis and IMF surveillance', Journal of Public Policy 31(2): 121-141.

Momani, B. (2005) 'Limits of streamlining Fund conditionality: IMF’s organizational culture', Journal of International Relations and Development, 8(2): 39-57.

Momani, B. (2017) 'Professional management consultants in transnational governance', in L. Seabrooke and L.F. Henriksen (eds) Professional Networks in Transnational Governance, Cambridge: Cambridge University Press: 245-265.

Nelson, S.C. (2014) 'Playing favorites: how shared beliefs shape the IMF’s lending decisions', International Organization 68(2): 297-328.

Neumann, I.B. and O.J. Sending (2010) Governing the Global Polity: Practice, Mentality, Rationality, Ann Arbor: University of Michigan Press.

O'Mahoney, J. and A. Sturdy (2015) 'Power and the diffusion of management ideas: the case of McKinsey \& Co.', Management Learning 47(3): 247-265.

Ortiz, F. and G. Tang (2006) 'Results-based management in the united nations in the context of the reform process', Geneva: Joint Inspection Unit.

Park, S. and A. Vetterlein (eds) (2010) Owning Development. Cambridge: Cambridge University Press. 
Park, S. (2017) 'Accountability as justice for the Multilateral Development Banks? Borrower opposition and Bank avoidance to US power and influence', Review of International Political Economy, 24(5): 776-801.

Reinsberg, B., A.E. Kentikelenis, T. Stubbs and L. King, L. (2019) 'The world system and the hollowing out of state capacity: how structural adjustment programs affect bureaucratic quality in developing countries', American Journal of Sociology 124(4): 1222-1257.

Reinsberg, B. K. Michaelowa, and S. Knack (2017) 'Which donors, which funds? bilateral donors' choice of multilateral funds at the World Bank', International Organization 71(4): 767-802.

Schofer, E. (2003) 'The global institutionalization of geological science, 1800 to 1990', American Sociological Review 68(5):730-59.

Scott, W.R. (2008) 'Lords of the dance: professionals as institutional agents', Organization Studies 29(2): 219-238.

Seabrooke, L. (2012) 'Pragmatic numbers: The IMF, financial reform, and policy learning in least likely environments', Journal of International Relations and Development 15(4): 486-505.

Seabrooke, L. (2014) 'Epistemic arbitrage: transnational professional knowledge in action', Journal of Professions and Organization 1(1): 49-64.

Seabrooke, L. and Nilsson, E.R. (2015) 'Professional skills in international financial surveillance: assessing change in IMF policy teams', Governance, 28(2): 237-254.

Seabrooke, L. and E. Tsingou (2015) 'Professional emergence on transnational issues: linked ecologies on demographic change', Journal of Professions and Organization 2(1): 1-18.

Seabrooke, L. and D. Wigan (2015) 'How activists use benchmarks: reformist and revolutionary benchmarks for global economic justice', Review of International Studies 41(5): 887-904.

Sending, O.J. and I.B. Neumann (2011) 'Banking on power: how some practices in an international organization anchors others' in E. Adler and V. Pouliot (eds) International Practices. Cambridge: Cambridge University Press: 231-254.

Sending, O.J. (2014) 'The international civil servant', International Political Sociology, 8(3), 338-340.

Sending, O.J. (2015) The Politics of Expertise: Competing for Authority in Global Governance, Ann Arbor: University of Michigan Press.

Sending, O.J., V. Pouliot, and I.B. Neumann (eds) (2015) Diplomacy: The Making of World Politics, Cambridge Studies in International Relations, Cambridge: Cambridge University Press.

Sharma, P. (2013) 'Bureaucratic imperatives and policy outcomes: the origins of World Bank structural adjustment lending', Review of International Political Economy 20(4): 667-686.

Stanley, L. (2016) 'Using focus groups in political science and international relations', Politics 36(3): 236-49. 
Stone, D. (2013) 'Shades of grey: the World Bank, knowledge networks and linked ecologies of academic engagement', Global Networks 13(2): 241-60.

Stroup, S.S. and W.H. Wong (2017) The Authority Trap: Strategic Choices of International NGOs, Ithaca: Cornell University Press.

Sturdy, A. and C. Wright (2011) 'The active client: the boundary-spanning roles of internal consultants as gatekeepers, brokers and partners of their external counterparts', Management Learning 42(5): 485-503.

Sturdy, A., C. Wright, and N. Wylie (2015) Management as Consultancy: Neo-Bureaucracy and the Consultant Manager, Cambridge: Cambridge University Press.

Thérien, J.P. (1999) 'Beyond the North-South divide: the two tales of world poverty', Third World Quarterly 20(4): 723-742.

Thérien, J.P. (2012) The United Nations and human development: from ideology to global policies, Global Policy 3(1): 1-12.

Thistlethwaite, J. and M. Paterson (2016) 'Private governance and accounting for sustainability networks', Environment and Planning C: Government and Policy 34(7): 1197-1221.

Thrift, N. (2008) 'A perfect innovation engine: the rise of the talent world', Distinktion 9(1): 115-140.

Tsingou, E. (2015) 'Club governance and the making of global financial rules', Review of International Political Economy 22(2): 225-256.

United Nations Joint Inspection Unit (2014) 'Use of non-staff personnel and related contractual modalities in the United Nations system organizations', JIU/REP/2014/8. Geneva: United Nations.

United Nations (2017) 'UNDP Strategic Plan 2018-2021“ Executive Board of the UNDP, UNFPA and UNOPS, DP/2017/38. New York: United Nations.

Vetterlein, A. (2012) 'Seeing like the World Bank on poverty', New Political Economy 17(1): 35-58.

Vetterlein, A. and M. Moschella (2014) 'International organizations and organizational fields: explaining policy change in the IMF', European Political Science Review 6(1): 143-165.

Wade, R.H. (2003). What strategies are viable for developing countries today? The World Trade Organization and the shrinking of 'development space'. Review of International Political Economy, 10(4): 621-644.

Weaver, C.E. (2008) Hypocrisy Trap: The World Bank and the Poverty of Reform. Princeton: Princeton University Press.

Weber, M. (1978) Economy and Society: An Outline of Interpretive Sociology, Vol. 1 \& 2, ed. G. Roth and C. Wittich, Berkeley: University of California Press.

Weiss, T.G. (2013) Humanitarian Business, Oxford: Polity Press. 
Wright, C., A. Sturdy and N. Wylie (2012) 'Management innovation through standardization: consultants as standardizers of organizational practice', Research Policy 41(3): 652-662. 